\title{
Effect of Organic and Mineral Fertilization on Root Growth and Mycorrhizal Colonization of Pea Crops (Pisum sativum L.)
}

\author{
Dimitrios BILALIS ${ }^{1 *}$, Anestis KARKANIS ${ }^{2}$, Foteini ANGELOPOULOU ${ }^{1}$, Ilias TRAVLOS ${ }^{1}$, Andreas \\ ANTONIADIS ${ }^{1}$, Georgia NTATSI ${ }^{1}$, Efstathia LAZARIDI ${ }^{1}$, Dimitrios SAVVAS ${ }^{1}$ \\ ${ }^{1}$ Department of Crop Science, Laboratory of Agronomy, Agricultural University of Athens, 75 Iera Odos \\ str., GR 11855, Athens, Greece \\ ${ }^{2}$ Department of Agriculture Crop Production and Rural Environment, University of Thessaly, Fytokoy \\ Str, GR 384 46, N.Ionia, Magnisia, Greece \\ *)corresponding author, e-mail: cbilalisdimitrios@yahoo.gr
}

BulletinUASVM Horticulture 72(2) / 2015

Print ISSN 1843-5254, Electronic ISSN 1843-5394

DOI:10.15835/buasvmcn-hort:11497

\begin{abstract}
To evaluate the effects of organic and conventional fertlization on root and soil quality of four different pea varieties (Pisum sativum L.), a spilt-plot experiment with four replications was conducted in 2014-15 in central Greece. The experimental factors were organic manure $1000 \mathrm{~kg} \mathrm{ha}^{-1}$ and NPK fertilizer $600 \mathrm{~kg} \mathrm{ha}^{-1}$, in the main plots and four pea varieties: Onward (commercial variety), Amorgos, Andros and Schinousa (local varieties) as subplots. The soil and root parameters that were determined are the following: mean weight diameter, macroporosity, penetration resistance, total nitrogen, organic matter, root density and arbuscular mycorrhizal (AMF) root colonization. The results indicated that the soil and root properties were influenced by organic fertilization but this effect is in direct correlation with the different pea varieties. The soil parameters of organic matter and penetration resistance influenced by the type of fertilization regardless of pea variety, with the values of organic matter to be significantly higher by using of organic fertilization compare to conventional and the values of penetration resistance to be significantly higher by conventional fertilization. While regarding the parameters of mean weight diameter of soil aggregates (MWD), soil macroporosity and soil total nitrogen were observed differences between the varieties, but independent of the type of fertilization. As concerns the root properties, the values of root density were different in all four pea varieties, but only for the variety Schinousa there were an increase of the root density derived from the type of fertilization and specifically from organic fertilization. As concerns the percentage of abscular muccorhizal fungi (AMF) colonization the highest percentace were recorded, in all four pea varieties, in organic fertilization compared to conventional, and in all traditional varieties,
\end{abstract}

Keywords: conventional fertilization, mycorrhizal colonization, organic fertilization, pea varieties, Pisum sativum $L$.

\section{INTRODUCTION}

Pulses are an excellent source of protein, complex carbohydrates, vitamins and minerals in the diets of millions of people, particularly in developing countries. Among the world's pulses, field peas (Pisum sativum L.) rank second to dry beans in production and consumption. Field pea (Pisum sativum L.) is a legume with great nutritional potential due to its high protein content and it has been suggested as an alternative protein source to soybean in countries where the former legume is not a native crop, or in situations where soybean cannot be used due to allergic reactions or intolerances (Davidsson et al., 2001).

Crop productivity can be increased by the application of chemical, organic and biological 
fertilizers (Elsheikh et al., 2009). Anthropogenic activities, and soil management in particular, are mostly responsible for disturbing the chemicophysical and biological equilibrium of soil, and there is increasing concern over their long-term effects on the soil ecosystem (Nannipieri et al. 1997). Long-term studies and effects of agrotechnical practice clearly indicate that mineral fertilization has the strongest influence on field crop yield. However, the use of inorganic fertilizers has not been helpful as it is associated with increased soil acidity and nutrient imbalance (Kang and Juo, 1980). Additionally, results of investigations carried out by Doran et al. (1996), Jenkinson (1982), Barabsz and Smyk (1997) and Gawronska (1997) have shown that mineral fertilization also strongly affects a number of microorganisms and qualitative selection of whole communities of soil microorganisms. Thus, the intensive cropping systems with fertilizer responsive crops that rely on high input of inorganic fertilizers often lead to non-sustainability in production and also pose a serious threat to soil health. The need to alternative practices that will make agriculture more sustainable and reduce costs of fertilizing crops has revived the use of organic fertilizers worldwide. The use of organic fertilizers is a major component of organic farming practices (Berner et al., 2008). Various kinds of organic materials such as animal manures, sewage sludge and crop residues are applied to soil to improve soil organic matter content and consequently, the physical, chemical and biological properties of the soil (Debosz et al., 2002).

Crop productivity traditionally puts emphasis on above-ground traits; however, below ground properties are equally important. The root system explores the soil to scavenge nutrients and water, thus root system architecture greatly influences how efficiently a plant acquires resources in a given environment (Pierret et al., 2007; Badri and Vivanco, 2009). Root architecture is impacted by abiotic environmental factors such as soil structure, oxygen and nutrient availability, water content and temperature, as well as biotic factors like plant genetic traits and soil microorganisms (Hodge et al., 2009; Rich and Watt, 2013). Beside root architecture the ability of a plant to mine nutrients from the soil depends on its uptake systems and the conversion of less plant-available nutrients to more accessible forms. All of these factors are influenced by the rhizosphere microbiota and its interactions with the plant (Wissuwa et al., 2009). Among soil organisms, arbuscular mycorrhizal (AM) fungi which function both within roots and in the soil matrix, are a vital component of the soil biota since they act as a link between plant and soil (Bethlenfalvay, 1992; Smith and Read, 1997).

Arbuscular mycorrhizal fungi (AMF) are ubiquitous in soil (Mosse et al., 1981) and colonize approximately $80 \%$ of all plant species, including field pea and lentil (Smith and Read, 1997). Arbuscular mycorrhizal fungi in general seem to thrive in soil amended with organic matter (Albertsen et al., 2006; Hodge et al., 2001). Clearly, agricultural management factors such as the intensity of cultivation, the quality and quantity of fertilizers applied and the plant protection strategies used may have severe impacts on the AMF community structure (Bilalis et al. 2009; Douds and Millner 1999; Oehl et al. 2003a; Sieverding 1989). Galvez et al. (2001) found that the abundance of spores of AMF was much lower in high input agriculture compared to that in low-input agriculture. Some species of AMF may even be severely depressed under conventional farming where mineral fertilizers are exploited (Oehl et al. 2004). On the other hand, organic fertilization may increase sporulation of some AMF species (Douds et al. 1997) or propagule density in the soil (Harinikumar and Bagyaraj, 1989). High diversity of fungal communities may be beneficial for crop production, especially high diversity of AM fungi may be an important factor in maintaining productivity and stability in sustainable agricultural ecosystems (Kjøller and Rosendahl, 2001; Unterseher et al., 2011).

The main objective of this study was to assess the influence of organic versus conventional fertilization on root and soil properties in four different pea varieties.

\section{MATERIALS AND METHODS}

A field experiment was carried out in central Greece (Aliartos, $95 \mathrm{~km}$ northwest of Athens) in 2014-15. The pea crop was sown on 20 November 2014. The experiment was laid out in a split-plot design with four replicates having two main plots (conventional and organic farming system) and four sub-plots (pea varieties: Onward (commercial variety), Amorgos, Andros and Schinousa (local varieties). Moreover, $600 \mathrm{~kg} \mathrm{ha}^{-1}$ of fertilizer (11- 
15-15, $\mathrm{N}: \mathrm{P}_{2} \mathrm{O}_{5}: \mathrm{K}_{2} \mathrm{O}$ ) and $10000 \mathrm{~kg} \mathrm{ha}^{-1}$ of farm yard manure was applied before sowing, in the conventional and organic plots, respectively.

The sampling date, for all plant and soil parameters, was 120 days after sowing. Soil bulk density and macroporosity was determined for each plot by collecting undisturbed soil cores from 0 to $35 \mathrm{~cm}$ depth using $100 \mathrm{~cm} 3$ cylinders (5 cm height and $5.04 \mathrm{~cm}$ diameter) (Lutz 1947). The Wakley \& Black method (1934) was used to determine the organic $\mathrm{C}$ content. The total nitrogen was determined by the Kjeldahl method (Bremner, 1960) using a Buchi 316 device in order to combust and extract the soil samples. Three samples of $100 \mathrm{~cm} 3$ per plot were takenIn order to determine macroporosity (MP) $(\mathrm{d}>10 \mu \mathrm{m})$ the Richards (1949) water extraction apparatus was used. Penetration resistance (PR) of the soil was measured using a digital penetrologger (Model 06.15, Eijkelkamp Equipment Ltd, Netherlands). The penetration resistance was determined in all plots at depth intervals of $1 \mathrm{~cm}$ within the 0-25 layer.Mean weight diameter (MWD) of aggregates was determined by using the oscillation apparatus Analysette 3, (Spartan, Fritsch Ltd, Oberstein, Germany) 110 days after sowing. The oscillation time was 3 min using 1 liter of fresh soil from 0 to $10 \mathrm{~cm}$ depth and mesh sizes of 20 to 40,10 to 20, 5 to 10,2 to 5 , and $<2 \mathrm{~mm}$. After separation of each aggregate class, the soil was dried at $105{ }^{\circ} \mathrm{C}$. The MWD equals the sum of the products of the mean diameter, $x i$, of each size fraction and the proportional weight, $\mathrm{w}_{\mathrm{i}}$, of the corresponding size fraction. For calculating the MWD, the following equation was used (Van Bavel, 1949).

$\mathrm{M} \Sigma \Delta \Sigma=\sum_{i=1}^{n} x i w i$

Where:

$\mathrm{xi}$ - the average diameter holes in sieves- density

wi - the weight ratio of particles remaining in sieves

Root samples were collected 110 days after sowing and from the 0 to $35 \mathrm{~cm}$ layer by using a cylindrical auger $(25 \mathrm{~cm}$ length, $10 \mathrm{~cm}$ diameter) at the midpoint between successive plants within a row. First, roots were separated from the soil by soaking the samples overnight in $30 \mathrm{ml}$ of a
$0.5 \%$ solution of sodium hexametaphosphate. Afterwards, the samples were stirred for $5 \mathrm{~min}$ and washed over a $5 \mathrm{~mm}$ mesh-sieve. The roots thus held on the sieves were decanted into a $0.1 \%$ trypan blue FAA staining solution (mixture of $10 \%$ formalin, $50 \%$ ethanol and 5\% acetic acid solutions). For the determination of root length density (RLD), the stained root samples were placed on a high resolution scanner (Hewlett Packard 4c, Palo Alto, CA, USA) and images captured using Delta-T software, (Delta-T Scan version 2.04; Delta-T Devices Ltd, Burwell, Cambridge, UK). The second root samples were cleaned and stained with trypan blue in lactophenol, according to the method of Phillips and Hayman (1970). The percentage of root length colonized by AM fungi was determined microscopically with the gridlineintersection method at a magnification of $\times 30$ to $\times$ 40 (Giovannetti \& Mosse, 1980).

The statistical analysis was performed with SigmaPlot 12 software (Systat Software Inc., San Jose, CA).

\section{RESULTS AND DISCUSSION}

The type of fertilization influences the soil and root properties, but this effect may vary considerably between different varieties.

As concerns the physical soil properties there were no statistically significant differences in mean weight diameter of soil aggregates (MWD) and soil macroporosity values among organic and conventional fertilization, but there were statistically significant differences between the four pea varieties (Table 1). Regarding MWD there were statistically significant difference between the varieties Onward and Amorgos with Andros and Schinousa, while as regards the soil macroporosity was observed statistically significant difference just among the varieties Onward and Schinousa. Contrary to MWD and soil macroporosity, there were a statistically significant difference between penetration resistance values among organic and conventional fertilization regardless variety, with conventional fertilization presenting significantly higher values (Table 1). AMF produce glomalin (an insoluble gluelike substance) and is a component of soil $\mathrm{OM}$ and improve the soil aggregate formation (Wright et al., 1996).

Regarding the chemical soil properties, manure fertilization enhanced the soil organic matter statistically significant compare to 
mineral fertilization in all pea varieties (Table $2)$. The particulate organic matter $-\mathrm{C}$ and $-\mathrm{N}$ concentrations have been found to be elevated in farming systems relying on organic fertility compared with those using synthetic fertilizers (Wander et al., 1994; Willson et al., 2001; Fortuna et al., 2003; Nissen and Wander, 2003). Composed of partially decomposed plant and animal residues, particulate organic matter is thought to be an energy source for microorganisms (Stevenson, 1994; Christensen, 2001) and has been connected to other indices of nitrogen supply and nutrient cycling. According to the percentage of total nitrogen there were no statistically significant the organic and conventional fertilization,but was observed statistically significant difference among the varieties Onward and Andros with Amorgos and Schinousa (Table 2).

As to root properties, concerning root density only the traditional pea variety Schinousa appears to correspond positively to organic system and fertilization compare to conventional. The root density differs statistically significant between all varieties but beyond the variety Schoinousa in other varieties this difference was not relate to the type of fertilization (Table 3 ). In relation

Tab. 1. Effect of crop system and variety on soil physical properties. Data with different letter are statistically significant for $\mathrm{p}<0.005$ with Tukey test. MWD:mean weight diameter, MP: macroporosity and Pen.Res : penetration resistance.

\begin{tabular}{ccccc}
\hline System & Variety & MWD (mm) & MP (\%) & Pen Res (Mpa) \\
\hline conventional & Onward & $11,35 \mathrm{a}$ & $13,5 \mathrm{a}$ & $2,22 \mathrm{a}$ \\
\hline conventional & Amorgos & $11,55 \mathrm{a}$ & $14,5 \mathrm{ab}$ & $2,01 \mathrm{a}$ \\
\hline conventional & Andros & $11,7 \mathrm{~b}$ & $14,5 \mathrm{ab}$ & $2,09 \mathrm{a}$ \\
\hline conventional & Schinousa & $11,905 \mathrm{~b}$ & $15 \mathrm{~b}$ & $2,11 \mathrm{a}$ \\
\hline organic & Onward & $13,05 \mathrm{a}$ & $15,5 \mathrm{a}$ & $1,83 \mathrm{~b}$ \\
\hline organic & Amorgos & $13,75 \mathrm{a}$ & $16,5 \mathrm{ab}$ & $1,82 \mathrm{~b}$ \\
\hline organic & Andros & $13,75 \mathrm{~b}$ & $16 \mathrm{ab}$ & $1,81 \mathrm{~b}$ \\
\hline organic & Schinousa & $13,6 \mathrm{~b}$ & $17,5 \mathrm{~b}$ & $1,75 \mathrm{~b}$ \\
\hline Fsystem & & & \\
\hline Fvariety & & $302^{* * *}$ & $42,7^{* * *}$ & $64,1^{* * *}$ \\
\hline F system ${ }^{*}$ variety & $5,5^{*}$ & $5,6^{*}$ & $1,64^{n s}$ \\
\hline & $1,34^{n s}$ & $0,44^{n s}$ & $1,41^{n s}$ \\
\hline
\end{tabular}

Tab. 2. Effect of crop system and variety on soil chemical properties. Data with different letter are statistically significant for $\mathrm{p}<0.005$ with Tukey test. $\mathrm{N}$ total: soil total nitrogen.

\begin{tabular}{cccc}
\hline System & Variety & N total (\%) & Organic matter (\%) \\
\hline conventional & Onward & $0,107 \mathrm{a}$ & $1,22 \mathrm{a}$ \\
\hline conventional & Amorgos & $0,116^{\alpha}$ & $1,25 \mathrm{a}$ \\
\hline conventional & Andros & $0,121 \mathrm{~b}$ & $1,29 \mathrm{a}$ \\
\hline conventional & Schinousa & $0,123 \mathrm{~b}$ & $1,27 \mathrm{a}$ \\
\hline organic & Onward & $0,132 \mathrm{a}$ & $1,48 \mathrm{~b}$ \\
\hline organic & Amorgos & $0,141 \mathrm{~b}$ & $1,47 \mathrm{~b}$ \\
\hline organic & Andros & $0,142 \mathrm{~b}$ & $1,58 \mathrm{~b}$ \\
\hline organic & Schinousa & $0,141 \mathrm{~b}$ & $1,60 \mathrm{~b}$ \\
\hline & & & $49,3^{* * *}$ \\
\hline Fsystem & $102,8^{* * *}$ & $1,39^{n s}$ \\
\hline Fvariety & $6,76^{*}$ & $0,29^{n s}$ \\
\hline F system*ariety & & $0,60^{n s}$ &
\end{tabular}


to the percentage of AM colonization the highest values, in all four pea varieties, were recorded in organic fertilization compared to conventional (Table 3). AMF respond markedly to the presence of organic matter in their environment (St.-John et al. 1983; Joner and Jakobsen 1995) as well as to organic fertilization and substrate additives (Gryndler et al. 2001; Joner 2000; Ravnskov et al. 1999). Fertilization is one of the most important agricultural managements influencing the population densities and activity of soil microorganisms. Repeated application of organic fertilizers can increase microbial biomass and improve soil biological functions by a direct supply of exogenous organic $C$ to the soil (Diacono and Montemurro 2010).

As show at Table 4 between traditionals and common variety the mean differents were statistical significant at significant level 5\%. And three traditional varieties had more than $40 \%$ root colonization by AMF (under organic system) and onward lower.

\section{CONCLUSION}

The results from the present study indicated that the root and soil properties were affected more positively by organic fertilization compare to conventional but in direct correlation with the cultivated variety. In relation to soil chemical and physical parameters were observed differences between organic and conventional fertilization, for all four pea varieties, just for the parameters of penetration resistance and organic matter. In case of organic matter the values were significantly higher to organic fertilization while in case of penetration resistance the opposite. For parameters of MWD, soil macroporosity and soil total nitrogen differences were found among some

Tab. 3. Effect of crop system and variety on root properties. Data with different letter are statistically significant for $\mathrm{p}<0.005$ with Tukey test. RD: Root Density and AMF: abscular muccorhizal fungi. The comparisons of mean at AMF given at Table 4.

\begin{tabular}{cccc}
\hline System & Variety & Root Density $\left(\mathbf{m m} / \mathbf{c m}^{3}\right)$ & \% AMF \\
\hline conventional & Onward & $1,41 \mathrm{~b}$ & 15,70 \\
\hline conventional & Amorgos & $1,28 \mathrm{a}$ & 16,75 \\
\hline conventional & Andros & $1,30 \mathrm{a}$ & 19,60 \\
\hline conventional & Schinousa & $1,28 \mathrm{a}$ & 22,15 \\
\hline organic & Onward & $1,48 \mathrm{~b}$ & 37,85 \\
\hline organic & Amorgos & $1,71 \mathrm{c}$ & 41,85 \\
\hline organic & Andros & $1,76 \mathrm{c}$ & 46,05 \\
\hline organic & Schinousa & $1,84 \mathrm{~d}$ & \\
\hline & & & 25,80 \\
\hline Fsystem & $151,2^{* * *}$ & $473^{* * *}$ \\
\hline Fvariety & $2,48^{n \mathrm{~s}}$ & $3.73^{\text {ns }}$ \\
\hline F system
\end{tabular}

Tab. 4. Comparison of mean for AMF and for variety factor

Comparisons for factor: Variety

\begin{tabular}{cccccc}
\hline Comparison & Diff of Means & $\mathrm{p}$ & $\mathrm{q}$ & $\mathrm{P}$ & $\mathrm{P}<0,050$ \\
\hline Schinousa vs. Onward & 7,2 & 4 & 15,008 & $<0,001$ & Yes \\
\hline Schinousa vs. Amorgos & 4,675 & 4 & 9,745 & $<0,001$ & Yes \\
\hline Schinousa vs. Andros & 1,15 & 4 & 2,397 & 0,385 & No \\
\hline Andros vs. Onward & 6,05 & 4 & 12,611 & $<0,001$ & Yes \\
\hline Andros vs. Amorgos & 3,525 & 4 & 7,348 & 0,004 & Yes \\
\hline Amorgos vs. Onward & 2,525 & 4 & 5,263 & 0,024 & Yes \\
\hline
\end{tabular}


of the varieties which are not related to the use of organic or inorganic fertilization. About the root parametes, the root density were observed to be mainly influenced by the variety and not by the type of fertilization since only the variety Schoinousa were displayed significantly higher values of root density under organic fertilization compare to inorganic. Concerning the percentage of abscular muccorhizal fungi colonization the highest amount were recorded, in all four pea varieties, in organic fertilization compared to conventional and at the traditional varieties the AMF colonization were higher. The root colonization by AMF is a property strongly correlate with traditional varieties.

Acknowledgments. Our work supported by by the European Commission within the project: "EUROLEGUME: Enhancing of legumes growing in Europe through sustainable cropping for protein supply for food and feed" (grant agreement no: 613781 CP-FP), which was carried out under the EFP7 Cooperation Theme 'Food, Fisheries and Biotechnologies'.

\section{REFERENCES}

1. Albertsen A, Ravnskov S, Green H, Jensen DF, Larsen J (2006). Interaction between the external mycelium of the mycorrhizal fungus Glomus intraradices and other soil microorganisms affected by organic matter. Soil Biology \& Biochemistry 38: 1008-1014.

2. Badri DV, Vivanco JM (2009). Regulation and function of root exudates. Plant, Cell and Environment 32: 666-681.

3. Barabsz W, Smyk B (1997). Mikroflora gleb zmeczonych. Zesz. Probl. Post. Nauk Roln: 452, 37.

4. Berner A, Hildermann I, Fließbach A, Pfiffner L, Niggli U, Mäder P (2008). Crop yield and soil fertility response to reduced tillage under organic management. Soil and Tillage Research 101, 89-96.

5. Bethlenfalvay GJ (1992). Mycorrhizae and crop productivity. In: Bethlenfalvay GJ, Linderman RG (eds) Mycorrhizae in sustainable agriculture. Special publication no. American Society of Agronomy, Madison, Wis: 1-27.

6. Bilalis D, Sidiras N, Vavoulidou E, Konstantas A (2009). Earthworm populations as affected by crop practices on clay loam soil in a Mediterranean climate. Acta Agriculturae Scandinavica-Plant Soil Science, 59:440-446.

7. Christensen, BT (2001). Physical fractionation of soil and structural and functional complexity in organic matter turn over. Eur. J. Soil Sci. 52:345-353.

8. Davidsson L, Dimitriou T, Walczyk T, Hurrel RF (2001). Iron absorption from experimental infant formulas based on pea (Pisum sativum)-protein isolate: the effect of phytic acid and ascorbic acid. British Journal of Nutrition 85: 59-63.
9. Debosz K, Petersen SO, Kure LK, Ambus P (2002). Evaluating effects of sewage sludge and household compost on soil physical, chemical and microbiological properties. Applied Soil Ecology 19: 237-248.

10. Diacono M, Montemurro F (2010). Long-term effects of organic amendments on soil fertility. A review. Agronomy for Sustainable Development, 30: 401-422.

11. Doran JW, Sarrantonio M, Liebieg MA (1996). Soil health and sustainability. Advance in Agronomy. 56:1.

12. Douds DD, Galvez L, Franke-Snyder M, Reider C, Drinkwater LE (1997). Effect of compost addition and crop rotation point upon VAM fungi. Agric Ecosyst Environ 65:257-266.

13. Douds DD, Millner P (1999). Biodiversity of arbuscular mycorrhizal fungi in agroecosystems. Agric Ecosyst Environ 74:77-93.

14. Elsheikh EAE, Mohamed SS, Elhussein AA, Babiker EE (2009). Effects of intercropping, Bradyrhizobium inoculation and chicken manure fertilization on the chemical composition and physical characteristics of soybean seed. Food Chem., 112: 690-694.

15. Fortuna A, Harwood RR, Paul EA (2003). The effects of compost and crop rotations on carbon turnover and the particulate organic matter fraction. Soil Sci. 168:434-444.

16. Galvez L, Douds DD, Drinkwater LE, Wagoner P (2001). Effect of tillage and farming system upon VAM fungus populations and mycorrhizas and nutrient uptake of maize. Plant Soil 228:299-308.

17. Gawronska A (1997). Zmianowanie roslin a zmeczenie gleb. Acta Acad. Agriclt. Tech. Olsst., Agricult.: 64-67.

18. Gryndler M, Hršelová H, Vosátka M, Votruba J, Klír J (2001). Organic fertilization changes the response of mycelium of arbuscular mycorrhizal fungi and their sporulation to mineral NPK supply. Folia Microbiol 46:540-542.

19. Harinikumar KM, Bagyaraj DJ (1989). Effect of cropping sequence, fertilizers and farmyard manure on vesiculararbuscular mycorrhizal in different crops over three consecutive seasons. Biol Fertil Soils 7:173-175.

20. Hodge A, Campbell CD, Fitter AH (2001). An arbuscular mycorrhizal fungus accelerates decomposition and acquires nitrogen directly from organic material. Nature 413: 297-299.

21. Jenkinson DS (1982). The nitrogen cycle in long-term field experiments. Phil.Trans.R.London B: 269, 569.

22. Joner EJ (2000). The effect of long-term fertilization with organic and inorganic fertilizers on mycorrhiza-mediated phosphorus uptake in subterranean clover. Biol Fertil Soils 32:435-440.

23. Joner EJ, Jakobsen I (1995). Growth and extracellular phosphatase activity of arbuscular mycorrhizal hyphae as influenced by soil organic matter. Soil Biol Biochem 27:1153-1159.

24. Kang BT, Juo ASR (1980).Management Of Low Activity Clay Soils In Tropical Africa For Food Crop Production. In Terry ER, Oduro K.A, Caveness F.(eds).Tropical Root crops: Research strategies for the 1980s. Ottawa, Ontario, IDRC: 129-133

25. Kjøller R, Rosendahl S (2001). Molecular diversity of glomalean (arbuscular mycorrhizal) fungi determined 
as distinct Glomus specific DNA sequences from roots of field grown peas. Mycological Research 105, 1027e1032.

26. Mosse B, Stribley DP, LeTacon F (1981). Ecology of mycorrhizae and mycorrhizal fungi. In: Alexander M (ed) Advances in microbial ecology, vol 5. Plenum, New York.

27. Nannipieri P, Badalucco L, Landi L, Pietramellara G (1997) Measurements in assessing the risk of chemicals to the soil ecosystem. In: Zelikoff JT (ed) Ecotoxicology: responses, biomarkers and risk assessment. SOS Publications, Fair Haven, NJ 07704 USA: 507-534.

28. Nissen TM, Wander MM (2003). Management and soilquality effects on fertilizer-use efficiency and leaching Soil Sci. Soc. Am. J.67:1524-1532.

29. Oehl F, Sieverding E, Ineichen K, Mäder P, Boller $T$ Wiemken A (2003a). Impact of land use intensity on the species diversity of arbuscular mycorrhizal fungi in agroecosystems of Central Europe. Appl Environ Microbiol 69:2816-2824.

30. Oehl F, Sieverding E, Mäder P, Dubois D, Ineichen K, Boller $\mathrm{T}$, Wiemken A (2004) Impact of long-term conventional and organic farming on the diversity of arbuscular mycorrhizal fungi. Oecologia 138:574-583.

31. Pierret A, Doussan C, Capowiez Y, Bastardie F, Pages L, (2007). Root functional architecture: a framework for modeling the interplay between roots and soil. Vadose Zone Journal 6: 269-281.

32. Ravnskov S, Larsen J, Olsson PA, Jakobsen I (1999). Effect of various organic compounds on growth and phosphorus uptake of an arbuscular mycorrhizal fungus. New Phytol 141:517-524.

33. Rich SM, Watt M (2013). Soil conditions and cereal root system architecture: review and considerations for linking Darwin and Weaver. Journal of Experimental Botany 64: 1193-1208.
34. Sieverding E (1989). Ecology of VAM fungi in tropical agrosystems. Agric Ecosyst Environ 29:369-390.

35. Smith SA, Read DJ (1997). Mycorrhizal symbiosis, 2nd edn. Academic Press, San Diego.

36. Smith SE, Read DJ (1997). Mycorrhizal symbiosis, 2nd edn. Academic, London.

37. St.-John TV, Coleman DC, Reid CPP (1983). Association of vesicular-arbuscular mycorrhizal hyphae with soil organic particles. Ecology 64:957-959.

38. Stevenson FJ (1994). Humus chemistry: Genesis, composition, reactions. 2nd ed. John Wiley \& Sons New York.

39. Unterseher M, Jumpponen A, Öpik M, Tedersoo L, Moora M, Dormann CF, Schnittler M (2011). Species abundance distributions and richness estimations in fungal metagenomics-lessons learned from community ecology. Molecular Ecology 20: 275-285.

40. Wander MM, Traina SJ, Stinner BR, Peters SE (1994). Organic and conventional management effects on biologically active soil organic matter pools. Soil Sci. Soc. Am. J. 58:1130-1139.

41. Willson TC, EA Paul, Harwood RR (2001). Biologically active soil organic matter fractions in sustainable cropping systems. Appl. Soil Ecol. 16:63-76.

42. Wissuwa M, Mazzola M, Picard C (2009). Novel approaches in plant breeding for rhizosphere-related traits. Plant and Soil 321: 409-430.

43. Wright SF, Franke-Snyder M, Morton JB, Upadhyaya A (1996). Time-course study and partial characterization of a protein on hyphae of arbuscular mycorrhizal fungi during active colonization of roots. Plant Soil. ;181:193203. 